\title{
Circumventing deadlock through venue-shopping: Why there is more than just talk in US immigration politics in times of economic crisis ${ }^{1}$
}

(date of acceptance, 2 March 2016, Journal of Ethnic and Migration Studies, Vol. 42, Issue 10, pp. 1590-1609)

\begin{abstract}
This article addresses the question of how the financial and economic crisis that hit the US in the late 2000s impacted immigration policies. We find that the crisis has not significantly changed dynamics. Instead, it has highlighted and aggravated persisting trends. Drawing on Kingdon's multiple streams model and combining it with the notion of two-level games, we find that while the policy stream and the problem stream would call for both restrictive and liberalising changes, the political stream impedes change: The fact that Congress has been divided for a long time over Comprehensive Immigration Reform (CIR) impedes any restrictive or liberalising changes. With problems resulting from current policies being intensified through the global economic crisis, however, actors favouring either restrictive or liberal policy change look for alternative venues to pursue their policy aims. Through legislative changes on the state level or via executive orders by the president, policies can be changed on a lower level without CIR.
\end{abstract}

Keywords: deadlock, economic crisis, immigration policies, multiple streams, USA, venueshopping

\section{Introduction}

The global economic and financial crisis since 2008 has proved to be a major challenge for the Western world. It resulted in both a rise in unemployment rates and a decrease in public spending in many European countries and the United States (US).

External shocks such as the economic crises have been found to substantially impact immigration policies in the past. Given the rise in unemployment and the decreased demand on the labour force, crises can be expected to produce 'a climate conducive to a restrictive regime' (Beets and Willekens 2009, 6; Newton 2008, 60). Cases in point are the Depression of 1920/21 in the US and the economic downturn following the oil crisis in the 1970s, both of

\footnotetext{
${ }^{1}$ The authors have contributed equally to this article and are presented in reverse alphabetical order. Natascha Zaun is a lecturer and researcher at the University of Mainz. Correspondence to: Natascha Zaun, Johannes Gutenberg Universität Mainz, Institut für Politikwissenschaft, Jakob-Welder-Weg 12, 55128 Mainz. Email:. Christof Roos is a Research Professor at the Institute for European Studies at the Vrije Universiteit Brussels. Correspondence to: Christof Roos, Vrije Universiteit Brussels, The Institute for European Studies, Pleinlaan 5, B-1050 Brussels, E-Mail: christof.roos@vub.ac.be. Fabian Gülzau is a lecturer and researcher at HumboldtUniversität zu Berlin. Correspondence to: Fabian Gülzau, Humboldt-Universität zu Berlin, Institut für Sozialwissenschaften, Unter den Linden 6, 10099 Berlin. E-Mail: fabian.guelzau@ hu-berlin.de. The interview data used was collected in 2012 as part of the research project "From Containers to Open States? Border Regime Change and the Mobility of Persons" at the Collaborative Research Centre 597 "Transformations of the State" at University of Bremen. The authors would like to thank Steffen Mau as head of the project and Heike Brabandt for conducting interviews with collective actors in the United States as part of this project.
} 
which led to the implementation of more restrictive immigration policies (Hatton and Williamson 2009). Yet at the same time, a crisis also makes more pronounced the hardships of undocumented immigrants that have no access to social benefits and thus suffer significantly when losing their occupation. Increased restriction of labour migration, moreover, can lead to migrants seeking access via humanitarian channels for refugee protection or family reunification (Czaika and De Haas 2013).

The recent crisis has been described as the worst financial crisis since the Great Depression by the International Monetary Fund (The Guardian, 10 April, 2008) and can thus be expected to have significantly impacted immigration policies in the US, as the US was hit particularly hard by the crisis (Huffington Post, 21 June, 2012; The Atlantic, 20 March, 2013). For instance, the US faced a substantial rise in unemployment and a GDP decrease in the crisis years from 2008 to 2012. This article aims at answering the question of how and to what extent the global economic crisis has impacted US immigration policies and politics.

We find that while there is no policy change induced by Congress, substantive changes at the state levels and through presidential Executive Orders can be observed. While policy change is blocked through deadlock in Congress, pressures from their constituencies for either liberal or restrictive changes encourage politicians to search for alternative venues to realise their policy aims. Actors interviewed for this study substantiate the claim that the crisis had an accelerating impact on policy change at levels other than Congress. We argue that this situation can be explained based on a combination of both venue-shopping as introduced by Baumgartner and Jones (1993) and the multiple streams model suggested by Kingdon (1995). While both the policy stream (i.e. policy ideas that are present among politicians and experts) and the problem stream (i.e. the non-functionality of the current immigration system) would call for change, the political situation of deadlock in Congress impedes change. The reason for impeded change is that both actors with liberal preferences and actors with restrictive preferences present in the Congress rather have incentives for defection than cooperation on the issue matter, as defection results in more favourable policy outcomes for each of them. They are more willing to accept the absence of the policy change they desire than they are willing to adopt changes to the status quo based on the policy preferences of their adversaries. Thus, proponents of restrictive change, such as political actors from (mainly Republican governed) US states that are affected disproportionately by undocumented immigration, foster restrictive change on the local level and adopt policy aiming at immigration control enforcement that has so far been blocked in Congress (Steil and Vasi 2014; Jones and Chou 2014). In contrast, examples for liberal change are the executive orders launched by President 
Obama aiming at temporary relief from deportation as well as the right to apply for work permits for certain undocumented immigrants.

With this study we aim to contribute to the wider debate on whether external shocks entail either restrictive or liberalising policy change. Our core finding is that while external shocks create pressures for change, these pressures need to be taken up by political actors in order to be transformed into actual policy change. Where change does not happen, pressures for change look for alternative venues and entail a politicisation of the issue. This study is based on an analysis of literature as well as policy documents on a number of decisions that have been made in the immigration policy area in the US between 2008 and 2012. In addition, we conducted 15 interviews in Fall 2012, at the height of the economic crisis, in which collective actors, such as unions and employers, but also politicians and experts from think tanks, elaborated on what they considered viable policies in times of crisis.

\section{Multiple Streams and Venue-Shopping as a theoretical framework to study policy change in times of crisis}

We aim at explaining the impact of the crisis on US immigration policies by drawing on Kingdon's multiple streams approach and combining it with the venue-shopping theory (Baumgartner and Jones 1993). According to Kingdon (1995), policy change can be explained by a convergence of the problem stream, the policy stream and the politics stream. Analogously, the lack of change is based on an absence of this convergence. In line with Kingdon, the problem stream means the issue or the policy problem to be addressed. The policy stream covers the policy ideas that aim at its solution. The politics stream is the institutional setting and the political actors involved. In this article, we argue that the absence of a political stream favourable to change can account for the policy deadlock that we observe in US immigration politics in Congress. Moreover, we argue that the absence of such a favourable political stream can be best explained by drawing on the deadlock game in game theory. Following this model, non-cooperation is most beneficial to all actors involved, both individually and collectively, which eventually leads to policy stasis. Yet, given the immense pressures for change by their constituencies, which were amplified through the economic crisis, we argue that proponents of change look for alternative venues to pursue their aims. Thus, we contribute to the empirically rich body of literature on policy stasis in the US (Mansbridge and Martin 2013; McCarthy 2007) by adding an as of yet missing theoretical explanation for this state of affairs. 
According to the multiple streams model, the policy stream concerns policy ideas that are constantly around in what Kingdon calls the 'policy primeval soup' (Kingdon 1995, 116). These policy ideas are usually based on different preferences. While some actors might be more concerned about immigrants' effective access to rights, others might favour a limitation of immigration levels or aim at more selectivity in immigrant admission. Based on these preferences, actors build ideas of both causal relationships (i.e. about what $i s$ ) and what could be policy responses to tackle problems. The policy ideas thus are solutions which they can sell to decision-makers. Yet, crucial events are needed for these policy ideas to get noticed and gain political weight (Kingdon 1995, 113). In fact, dissent about the number, nature and national origin of desirable immigration is a constant feature of the US debate (Zolberg 2008 [2006]). At the same time, immigrants are depicted as 'villainous invaders' and 'heroic founders' (Newton 2008, 1). Thus, a crisis entailing a rise in numbers of unemployment can arguably help promoters of restriction of immigration gain ground (Newton 2008, 60). These could use the event to argue for a cut in immigration to ensure a stronger protection of national workers. Simultaneously, a crisis highlights the hardship undergone by undocumented immigrants as their socio-structural position makes them especially vulnerable to economic slumps (Tilly 2011; Papademetriou and Terrazas 2010). Yet, to implement restrictive or liberalising policy changes, the political stream has to come in as well. The political stream comprises things such as 'the public mood, pressure group campaigns, election results, partisan or ideological distributions in Congress, and changes of administration' (Kingdon 1995, 145). For instance, it has been argued that the increasing number of Latino voters puts pressure on the Democrats to introduce liberalising changes for the legalisation of their as of yet 'illegal' family and friends. In 2005, 84\% of the Latino population supported the legalisation through the so-called 'path to citizenship' (Suro 2005, 10). We assert that it is particularly the political stream which impedes change in Congress through deadlock. According to game theory, actors involved in a deadlock game benefit rather from defection than from cooperation. In this sense the game is a zero sum game. Each actor would benefit most in case of their own defection and the cooperation of the other actor. Yet, the second best outcome for actors would be that both of them defect. The least beneficial outcome for either of them would be obviously their own cooperation and the defection of the other actor. Thus, an outcome where both of them defect is highly likely.

However, with the crisis, the problem stream that supports the preferences of proponents of both liberal and restrictive change swells and their policy ideas face a rising demand with the electorate, at least in some highly affected states (Fetzer 2006). Thus, with 
deadlock in Congress, politicians need to look for alternative political venues (Baumgartner and Jones 1993) to pursue their aims and satisfy their constituencies. Our time of observation (2008-2012) spans, at least partly, from the $110^{\text {th }}$ (2007-2009) to the $112^{\text {th }}$ Congress $(2011-$ 2013). During the $110^{\text {th }}$ Congress under the Bush administration, the House of Representatives as well as the Senate had a Democrat majority. ${ }^{2}$ In the $111^{\text {th }}$ Congress, Obama was presiding over a Democrat majority in the House and Senate. Eventually, Republicans gained the majority in the House of Representatives in the $112^{\text {th }}$ Congress, however, still under Obama administration. Generally, immigration politics in the US is divisive and politicians do not necessarily hold uniform positions that reflect a party platform (Illias, Fenelly, and Federico 2008: 748). On specific issues, however, a partisan divide has become visible. Republicans more often prefer restrictive policies, particularly as regards border enforcement (Fetzer 2006; Milner and Tingley 2008). Democrats, on the other hand, have stronger preferences for the legalisation of undocumented immigrants (Lopez and Minushkin 2008, Boyer 2012, 2-3).

We argue that the situation of deadlock in Congress in combination with the crisis makes policy-makers particularly susceptible to the dynamics of venue-shopping. While US policy-makers have already passed immigration policies in alternative venues before the beginning of the crisis, we argue that dynamics of venue-shopping in this area have intensified with the crisis.

Republicans searched for venues where they did not encounter liberal veto players. The Democrats could circumvent restrictive veto players through presidential Executive Orders, which the president was able to pass without any interference of the opposing party in Congress. How the crisis promoted this search for alternative venues can be shown by applying the multiple stream model to US immigration politics.

\footnotetext{
${ }^{2}$ The Senate was evenly split between Democrats and Republicans (49-49). However, two independent members voted with the Democrats.
} 


\section{The Problem Stream: An ineffective immigration system in times of economic crisis}

The US immigration system in the 2010s is widely acknowledged as dysfunctional. Not only has President Obama characterised the system as 'broken', but there is also consensus in scholarly debates that the current status quo is 'bad for migrants, employers and the national interest' (Martin 2011a, 24). This is especially due to high hurdles immigrants face. Unless someone has family-ties to US citizens, it is quite difficult to immigrate to the US. Visa streams for high- and low-skilled immigrants are criticised as they are overly complex and do not match business demands adequately (Hansen 2009, 11-13; Hanson 2009, 4). In addition, a large number of undocumented immigrants entered the country in the past two decades, of which some moved to states that did not previously have experiences with immigration (Jones-Correa 2012, 4) ${ }^{4}$. The latest estimates from January 2012 suggest an overall number of 11.4 million undocumented immigrants residing in the US, with a share of $59 \%$ being of Mexican origin (Baker and Rytina 2013). It is estimated that 30-45\% of the unauthorised population legally entered the country but then overstayed their visa (Hanson 2009, 3; Pew 2006). ${ }^{5}$ The economic crisis hit legal and, in particular, undocumented immigrants most severely, as sectors in which many immigrants had previously found employment (i.e. construction, retail and food) were highly affected by the economic downturn (Papademetriou and Terrazas 2010, 44-46; Tilly 2011, 679; Green and Winters 2010: 1068). Scholars, moreover, found that the economic crisis led to stagnating numbers in the (estimated) population of undocumented immigrants or even decreasing undocumented immigration (Hoefer, Rytina, and Baker 2012, 1).

The last major legislative reforms addressing the shortcomings of the US immigration system were the Immigration Reform and Control Act (IRCA) in 1986, the Immigration Act of 1990 and the Illegal Immigration Reform and Immigrant Responsibility Act (IIRIRA) in 1996 (Schain 2012, 210-215; Migration Policy Institute 2013). While IRCA tried to tackle the situation of a growing population of undocumented immigrants with amnesty and employer sanctions, the Immigration Act of 1990 aimed especially to raise the numbers of skilled

\footnotetext{
${ }^{3}$ Obama did so, for instance, in a speech at the American University on 1 July 2010, https://www.whitehouse.gov/the-press-office/remarks-president-comprehensive-immigration-reform (accessed: 08.07.2015).

${ }^{4}$ In fact, according to Jones-Correa (2012) the seven states with the largest growth in immigrant population (North Carolina, Georgia, Arkansas, Nevada, Tennessee, South Carolina, and Nebraska) in the period from 1990 to 2009 'had attracted significant numbers of immigrants before 1990' (4). What is more, Steil and Vasi (2014, 1134) showed that the Latino population growth is a strong and significant predictor of the adoption of antiimmigrant ordinances at the local level in the period from 2006 to 2011.

${ }^{5}$ However, those numbers vary dramatically, depending on the country of origin. For instance, while Mexicans rather cross the border uninspected, individuals from other Latin American countries rely on tourist visas to enter the United States and then become visa-overstayers (Massey and Riosmena 2010, 304).
} 
workers through the creation of the H-1B visa program (Schain 2012, 210-215, 104 Stat. 4978, §205). In addition, the IIRIRA combined greater border enforcement with a cut in social security benefits for immigrants (i.e. Social Security Federal public benefits, 110, Stat. 3009; see also Newton 2008, 53-63). Moreover, the IIRIRA enabled 'local and state police [...] to enforce federal immigration law' (Varsanyi 2010, 2) under provision 287(g). This is remarkable paradigm shift since immigration enforcement was an exclusive federal competence with states having "virtually no role in the construction or enforcement of immigration law' (Wishnie 2002, 285) ${ }^{6}$. Nevertheless, IRCA was unsuccessful in diminishing the inflow of undocumented migrants and the Immigration Act of 1990 played its part in increasing the complexity of the immigration system (Schain 2012, 213; Martin 2011b, 80). Not surprisingly, the widely acknowledged problems of the current US immigration policies also influence public opinion. The Pew Research Center $(2013,2)$ found that $75 \%$ of the respondents see the need for at least major changes in the US immigration system. More precisely, the same survey observed that while three-fourths of the respondents want a possibility for undocumented immigrants to stay legally (73\%) and think that the government can do more to reduce undocumented immigration (a lot more: 53\%; somewhat more: 30\%), there is little consensus on whether to increase or reduce legal immigration (increase: 25\%, decrease: $36 \%$ ).

In sum, the 'problem stream' of US immigration policies is that the immigration system is considered dysfunctional by the majority of policy-makers involved. Both proponents of restriction (e.g. in the areas of border protection or family immigration) and liberalisation (e.g. concerning legalisation of immigrants already in the country or supporters of increased immigration by labour) do not benefit from the system as it is. In the following section we will show that while all actors agreed that the immigration system needed to be reformed, the policy ideas to fix the broken system varied significantly between the actors.

\section{The Policy Stream: Ideas for the reform of an ineffective immigration policy}

This section demonstrates that the comprehensive immigration reform (CIR) comprises a set of major ideas for reinvigorating the effectiveness of US immigration policy. According to

\footnotetext{
${ }^{6}$ In this regard the IIRIRA can be seen as a prerequisite to devolution in the field of immigration policies. Additionally, the Personal Responsibility and Work Opportunity Reconciliation Act (PRWORA) and the Antiterrorism and Effective Death Penalty Act (both in 1996) were part of this development. While the PRWORA cut down legal immigrants' eligibility for social services (i.e. Food Stamps, Medicaid) and 'devolved authority over select social services to the states' (Varsanyi 2010,2), the latter 'gave local police the authority to arrest previously deported noncitizen felons' (Varsanyi 2010; Wishnie 2002).
} 
Kingdon, policy ideas need to be on the floor already for actors to take them up and translate them into policy change. We will show how actors' preferences either coincided or collided with the CIR in times of economic crisis. Against the background of the picture drawn in the previous section, CIR - including border enforcement, regularisation of the undocumented and a guest worker scheme - becomes a compelling solution to the problems of the US immigration system. Since the 2000s, various forms of CIR have been debated in the US (for a history of proposed CIRs cf. Rosenblum 2011). Moreover, two presidents supported a CIR, although until now with little effect (Hanson 2009, 3). 'Comprehensive immigration reform' not only entails the promise of fixing an ineffective immigration policy, but also insinuates that actors would be more willing to agree on a package deal rather than individual policy. Comprehensiveness means that every major stakeholder's primary interest would be achieved, while at the same time the adoption of all policies would entail compromises on actors' positions (Freeman 2009, 65-69; Rosenblum 2011, 10-13). Put differently, every stakeholder receives something, while having to give in on other issues. CIRs in the past entailed - in different compositions - 'increased enforcement, a guest worker scheme and a path to legalization' (Freeman 2009, 69; Rosenblum 2011, 1). These three elements of immigration reform are key areas of US immigration policy. A CIR would tackle all of these policy areas. First, the call for increased enforcement touches upon border control, primarily at the southern US border, and stepping up internal control measures by means of ID and status checks at the work place ('E-verify') as well as in public places. Second, the expansion of guest worker schemes is meant to broaden the legal channel for the temporal demand for low- and highlyskilled labour. Such measures accommodate the demands of industry and business for a steady supply of labour. Third, with legalisation the estimated ten to twelve million undocumented migrants in the US would be getting the opportunity to legalise their status. Interestingly, points that are also debated, namely the significance of family reunification or the problem of visa overstaying, do not expand into proposals for a CIR. The rationale of a CIR is to get the approval of all stakeholders by implementing parts of their agenda and making 'package deals' (Marquez and Witte 2009, 3). Accordingly, actors worried by the level of undocumented immigration should be won for the reform by the plan to step up border control and internal enforcement. Amnesty on a broad scale could win the consent of unions and civil rights groups traditionally concerned with measures protecting people from exploitation. Employers' interest in labour supply is met by the offer of temporary labour migration programmes (Freeman 2009, 65-69; Rosenblum 2011, 10-13). 
In 2012 the slim chance for an agreement on this package deal disappeared in light of the economic crisis. ${ }^{7}$ The research on actors that promoted either legalisation of undocumented immigrants or temporary labour migration for skilled and unskilled workers felt that they had a harder time lobbying for their cause (Interview Chamber of Commerce, National Council of la Raza (NCLR) 2012). All collective actors who we have interviewed, regardless of political affiliation, see the crisis as a reason for an increasing polarization of opinions in the immigration policy area (Interviews US 2012). In particular, those parts of the comprehensive immigration reform package were met with resistance that not only debated closure, but also legalisation of the undocumented and openness for select groups of migrant workers. Concerning the debate, representatives of think tanks leaning to both the left and right confirmed that immigration had become a highly politicised topic. A policy advisor from the left-leaning think tank, the National Immigration Forum (2012), confirmed, that '[i]t is controversial to talk about the idea of foreign born individuals coming to the US when there are people here who are struggling to survive, who are native born Americans.' Speaking more bluntly, a representative from the conservative Center for Immigration Studies (2012) held that 'people do not have jobs, and they see illegal aliens having jobs. And we, as Americans, do not have them. So, there are numbers of levels of outrage that have caused devastation.'

In a nutshell, there are a variety of policy ideas on how to reform the US immigration system. These address different aspects of the immigration system and are underpinned by different ideological positions. Some actors, for instance, consider border enforcement crucial to minimise the inflow of undocumented migrants from Mexico. Others, in contrast, hold that creating legal paths to immigration, e.g. through guest worker schemes could help addressing this issue. Yet another group of stakeholders suggests that the hardship of those already staying in the country undocumented should be alleviated through regularisation. The presence of policy ideas for reform is an essential prerequisite in Kingdon's multiple streams model. However, these policy ideas need to be taken up by policy-makers in the political process.

In the next section, we will demonstrate that the politics stream was not favourable for substantive policy change on the federal level. While the crisis increased pressure for change, it further politicised the issue and clearly separated the policy streams from one another. The

\footnotetext{
${ }^{7}$ In 2006 a CIR was passed through a bipartisan initiative by Senators McCain (Republican) and Kennedy (Democrat) in the Senate. However, facing mid-term elections and increasing negative public opinion on the regularisation of undocumented migrants, the bill did not pass the House of Representatives. Instead, the rather sudden anti-immigrant backlash lead to the adoption of the Secure Fence Act, reinforcing border control at the US southern border (Rosenblum 2011, 7-8).
} 
different stakeholders hence grew even more apart from each other's positions. Given the divisiveness of the topic of immigration, the candidates in the 2012 presidential election did not address this issue. A unionist observed: '[P]olitical campaigns avoid the topic like the plague. You will see very little about immigration, if anything at all, in the current presidential campaign. From the politicians' standpoint, immigration is just a divisive issue on all sides' (Interview AFL-CIO 2012).

\section{The Politics Stream: Why there is deadlock in Congress over immigration reform}

Compromise among actors proved to be impossible since the crisis not only highlighted the divisiveness of the positions among actors but also because defection and maintenance of the status quo was more beneficial for actors than cooperation. This uncompromising stance in combination with institutional constraints in congressional politics reinforced deadlock over immigration reform. The US Congress is not only divided on content, but is also blocked institutionally. The US political system contains 'multiple veto points' (Rosenblum 2011, 11; Hansen 2009, 13): For instance, the presidential veto or the Senate filibuster (Martin 2013; Fennelly, Pearson and Hackett 2015, 1424). US bicameralism makes it necessary that both chambers agree on a bill for it to become law. In the US system, politicians' interest representation does not necessarily overlap with general party positions. Even though Democrats have a broader immigrant constituency than Republicans, leading to a more proimmigration and pro-rights attitude (Schain 2006, 386), US politics leave room for very local and specific interests (Interview Republican Senator 2012). Positions of politicians in the House of Representatives or Senate are defined by the interest of their respective constituencies, as well as business, unions, and other groups in these constituencies (Facchini and Steinhardt 2011, 735). Thus, it cannot be assumed that Republicans would show a tough stance on undocumented migration and call for border enforcement while Democrats would all be in favour of immigration and the granting of rights to the undocumented. In fact, Republicans that are open to the interests of business in their constituency, for example in the agriculture, hotel, and tourism industries, can turn a blind eye on efforts for border enforcement against undocumented immigration. Similarly, the Democrats' assumed liberal stance on immigration into the US could be obstructed by organised labour, claiming the depression of wages due to immigration (Interview AILA 2012). The interests of the main stakeholders, capital and labour, can be decisive in US immigration politics. Their influence on political groups can further impede compromise. We interviewed representatives of two union umbrella organisations: the AFL-CIO (American Federation of Labor and Congress of Industrial Organizations) representing 13.5 million workers, and the smaller Change to Win 
Federation (4.2 million members) which speaks for many Latino workers. Both unions strongly support an immigration reform that focuses on the rights of both migrant and native workers. The unions' policies to improve access to rights as well as working conditions includes the legalisation of the undocumented, opposition to temporary guest worker programmes, and a focus on worksite enforcement instead of border enforcement. For a representative of the AFL-CIO, the essence of immigration reform boils down to 'employer accountability' (Interview AFL-CIO 2012). If migrant workers are able to claim rights with their employer and these rights are enforced at the worksite, exploitation of workers because of unfair working conditions can be reduced. Hence, an amnesty for the undocumented is an indispensable condition for claiming rights (Interview Change to Win 2012). From the interview data it can be deduced that for unions, border enforcement is less of an issue as long as illegal employment is contained. The representatives of labour claim that employment opportunities for the undocumented create an incentive for crossing the border unauthorised. Unions criticise employers for 'fabricating' labour shortages in order to claim for the expansion of temporary worker programmes (Interview AFL-CIO 2012). Those programmes are not only said to affect wages negatively (Borjas 2005), but are also said to put the migrant worker in a dependent relationship with the employer since the working contract and residence status are combined (Interview AFL-CIO 2012). The rights focus of unions, as well as an interest in gaining more members, explains their opposition to temporary labour migration schemes and their lobby for legalisation. Thus, they would rather keep the status quo than compromise their position on temporary labour migration.

On the employers' side, the US Chamber of Commerce, which represents the interests of 3 million American businesses, considers immigration to be a tool for securing the economy's supply of labour. The focus of employers' lobbying efforts is on expanding temporary worker programmes, for highly as well as lesser skilled migrant workers. In this regard, opposition towards the unions' position is strongest (Interview US Chamber of Commerce 2012). The Chamber views measures that improve worksite enforcement of immigration and labour law critically, but is not opposed to them. Employers claim a system that only applies to new hires leaves room to maintain undocumented employees in their workforce. However, this would not mean opposition to legalisation of undocumented immigrants. Employers have an interest in a 'stable workforce'. The argument in favour of legalisation builds on immigrants' contribution to the economy and compliance with a set of 'strict criteria' that would allow undocumented migrants to earn citizenship. ${ }^{8}$ A steady supply

\footnotetext{
${ }^{8}$ See US Chamber of Commerce 'Fixing our Broken Immigration System'
} 
of workers in all sectors fuels production and keeps wages, also for the highly skilled, lower (Borjas 2005). Although US employers face strong opposition from unions with regard to temporary labour migration programmes, common ground on the issue of legalisation can be observed. Therefore, legalisation is the area in which policy output was most likely.

For the US Chamber of Commerce, immigration is part of the 'American Fabric' which, managed in an orderly way, has an overwhelmingly positive impact on the economy and society. Whether immigration is still 'vitally important to the success' (National Immigration Forum 2012) of the US is questioned by some actors. The position of two lobby groups, Numbers USA as well as FAIR (Federation for American Immigration Reform) show how a high level of immigration to the US and suggestions for regulatory reform have become a heavily contested issue. The positions of FAIR and Numbers USA would mean a radical change to the idea of immigration as being part of the American Fabric. They want to substantially lower immigration levels and push strongly for the enforcement angle of the Comprehensive Immigration Reform. As a consequence, their influence on policy-makers renders compromise on a comprehensive reform package cumbersome since expansion of admission for temporary workers and legalisation of undocumented workers are fundamentally opposed (Beirich 2009; Tichenor 2014, 43-45). ${ }^{9}$

Both groups argue that high levels of immigration impact negatively on social justice in the US as well as on the environment. The focus of restriction-minded groups on welfare systems and social justice can be observed since the 1990s. The framing of immigration as a welfare issue replaced a former discourse that racialised the immigration issue (Schain 2006, 384). They claim that population growth based on immigration has a negative impact on wages, the distribution of welfare benefits, as well as the environment in the US. The latter point of criticism is based on 'urban sprawl' related to population growth and needs for housing. Roy Beck, an environmentalist and founder of Numbers USA, sees the American worker with lower skills and lower education being harmed by immigration. Pressure on wages particularly in the low-skilled sector would contribute to massive social injustice. At the same time, immigrants are blamed for being 'net users of government services' (Interview Numbers USA 2012). The same relationship between immigration and local poverty is made by FAIR (2012): 'We cannot afford to support the impoverished ranks if we continue to keep

http://immigration.uschamber.com/uploads/sites/400/Summary\%20Immigration\%20Priorities\%20in\%20the\%20 House\%207-16-2013.pdf, accessed 10 October 2014.

${ }^{9}$ The pro-immigrant Southern Poverty Law Center accuses FAIR and Numbers USA of pursuing a nativist agenda. The Center accounts for the lobby groups' influence on US immigration politics, in particular the failure of the DREAM Act as well as Comprehensive Immigration Reform. http://www.splcenter.org/getinformed/publications/the-nativist-lobby-three-faces-of-intolerance, accessed 15 June 2015 
bringing in more and more. We do have a responsibility to the people of the US who are poor or do not have health insurance.' Concerning the economic crisis, it is criticised that immigration policy does not respond to changes in supply and demand for workers on the labour market. 'We are admitting the same number of people now our unemployment is over 8 per cent, as we did when it was under 5 per cent. [...] how do we fix the immigration system that addresses the needs we have in this country?' (Interview FAIR 2012). Both groups aim for 'population stability', i.e. the end of population growth induced by immigration. This would entail the reduction of immigration to one-quarter of its current size of one million admissions per year. In order to achieve this threshold, the green card and diversity lotteries would be abolished, family-based migration would be reduced to spouses and children only, and border and worksite enforcement would be increased. Immigration would not be stopped, because in terms of labour migration, a strict focus on immigration of the highly skilled is claimed. According to their own evaluation, FAIR and Numbers USA were successful in lobbying Congress against legalisation of the undocumented (Beirich 2009, 12, 18; Interview FAIR and Numbers USA 2012). Both lobby groups consider the status quo in US immigration regulation, which currently allows a million people each year to immigrate, to benefit the parties' families and business interests. Allegedly, immigration policy change should not be expected from Congress since immigrants are likely to increase the Democrats' electorate and Republicans please their 'backbone', the industry and business with a steady supply of labour (Interview Numbers USA 2012).

[Figure 1 about here]

Figure 1 provides information on interest groups and their objectives in a CIR. Points at the outer side of the triangle indicate support of i.e. stricter enforcement measures, while points in the centre show interest group position against this part of CIR. As explained above, stakeholders' and interest groups' positions are extremely divisive on the issue. On the one hand, the Latino civil rights organization NCLR and the labour union AFL-CIO support an amnesty for unauthorised immigrants already residing in the US, while being opposed to extended enforcement. Their liberal position is partly supported by the US Chamber of Commerce. They, however, strongly favour temporary labour migration programmes that are not supported by the unions. On the other side of the 'ideological (...) divide' (Marquez and Witte 2009, 20), the nativist organizations FAIR and Numbers USA are opposed to any part of CIR except extended enforcement. Following the deadlock game in game theory, defection 
is indeed more beneficial than cooperation, as currently none of the actors want to compromise their position on: the increase in labour force (employers), no temporary labour migration policy (unions), and stepping up in enforcement (nativists).

Studying actors' divisiveness over a comprehensive immigration reform, Martin (2011a, 25) holds that the status quo is the second-best option for those who cannot achieve their first-choice solution' as 'most unauthorised migrants get the higher wage jobs they seek and most employers get work done cheaper with such migrants' (Martin 2011a, 17) ${ }^{10}$. Therefore, he observes 'talk but no action' (Martin 2011a, 32) in times of crisis. We contest this argument and show in the next sections how actors searched for alternative venues to bring about change in immigration policy.

\section{In Search of New Venues: Immigration control at the state level and executive orders by the president}

The politics stream impeded change on the federal level due to the institutional setting and the divisiveness of actor positions which were emphasised by the crisis. Yet the problem stream became more prominent in recent years, especially but not only through the crisis and highlighted the need for policy change. This pressure hence led stakeholders to look for other venues to pursue their policy aims in which they would face fewer veto players.

Therefore, we find the claim that US politics were completely unable to produce legislative change to be slightly inaccurate. Change can be observed, albeit not on the federal level. Immigration policy-making shifts to the US states as well as to the president (Varsanyi 2010) ${ }^{11}$. Against the procedural rules that are laid down in the Constitution, the 'states take immigration into their own hands' (Interview Immigration Policy Center 2012). Such policy devolution can be observed in southern US states most affected by undocumented border crossers. Recent anti-immigrant legislation in Arizona and Alabama that aims against undocumented immigrants' access to government services, such as education or infrastructure, have caused concern among policy observers (Boyer 2012, 1). Not only are states overstepping their competencies in this field, state legislation is overwhelmingly targeted at undocumented immigrants, of whom many happen to be Latinos, causing fear of a backlash against workers from Mexico or Central America (Interview National Immigration

\footnotetext{
${ }^{10}$ A similar explanation for the inability reform is put forward by Hanson (2009).

${ }^{11}$ A minor exemption is the American Recovery and Reinvestment Act (ARRA) of 2009 which entailed restrictions on the $\mathrm{H}-1 \mathrm{~B}$ visa program for companies that received funds through the Troubled Asset Relief Program (TARP). However, the legislation only affected a small number of enterprises mainly in the banking sector and expired in 2011.
} 
Forum 2012). In addition, anti-immigrant ordinances issued by municipalities (local level) are constantly on the rise since the failures of Comprehensive Immigration Reform (Steil and Vasi 2014, 1110; Varsanyi 2010, 11; Gilbert 2009).

Since the late nineteenth century, immigration policy-making has laid in the hands of the federal government. Only recently 'state and local immigration policy activism has exploded' (Varsanyi 2010, 9). This devolution was made possible by the $104^{\text {th }}$ Congress under Republican majority through three aforementioned legislative acts that passed Congress in 1996: the Personal Responsibility and Work Opportunity Reconciliation Act (PRWORA), the Antiterrorism and Effective Death Penalty Act and the Illegal Immigration Reform Immigrant Responsibility Act (IIRIRA) (Varsanyi 2010, 2). ${ }^{12}$ However, state and local actors did not use these newly created channels immediately at the time of establishment (Varsanyi 2010). Varsanyi $(2010,11)$ argues that politicians became more active on the state and local levels to 'earn political capital on the issue of immigration reform'. Only the repeated failures to reform the immigration system 'opened a veritable Pandora's Box of state and local immigration control initiatives seeking to fill the policy void' (Cornelius 2010: vii). Case in points are the 287(g) agreements between the U.S. Immigration and Customs Enforcement agencies (ICE) and local enforcement partners (police), which are by now in place in 17 states (ICE 2014; Coleman 2012), municipalities and city ordinances (Steil and Vasi 2014; Varsanyi 2008). In terms of party politics, scholars showed that Republicans are critical of the effectiveness of federal measures for immigration enforcement and push for devolution to the state level. In contrast, Democrats are opposed to state government attempts to take on immigration enforcement (Jones and Chou 2014; Fennelly, Pearson and Hackett 2015, 1423).

Another example for a shift in venues are executive orders adopted by the president. These orders supersede majorities in the Congress and again highlight the inability of Congress to legislate. The DREAM Act, which would have legalised the status of young deserving undocumented migrants who had come as children, did not gain a majority in the Senate. Republican Senators blocked the bill in 2010. By executive order, President Obama bypassed approval of the Congress allowing for deferred action, abolishing execution of deportation for this specific group in August 2012. Among others, requirements for qualification are that undocumented youth must have no criminal record and pursue either military service or higher education. Legalisation was conditioned upon their 'deservingness'.

\footnotetext{
${ }^{12}$ In fact, these restrictions can be seen as the results of earlier venue shopping. Judicially inhibited restrictions on access of the undocumented to public goods in California (Proposition 187) influenced immigration control legislation in the US Senate and the creation of legal options for devolution. In the early 1990s, economic crisis, recession and unemployment put pressure on state politicians to act against undocumented immigrants (Schain 2006, 383-384).
} 
The justification for the original bill was not only based on moral grounds such as fairness; the group in question was brought to the country by their parents and thus had not broken immigration law intentionally. Additionally, the White House referred to the economic crisis and the positive budgetary implications that legalisation of this group would entail: 'President Obama believes that $[\ldots]$ an important part of rebuilding our economy [...] is making our immigration system functional, efficient, and accountable ${ }^{13}$ Economic and security needs justified pressing for passage of comprehensive immigration reform as well as the DREAM Act. It was calculated that passing the DREAM Act would bring $\$ 2.2$ billion revenue over ten years. ${ }^{14}$ The executive order was not only the adoption of a first piece of the deadlocked comprehensive immigration reform, but was also framed as a response to the crisis. In that sense, not only could venue shopping be observed, but also the intersection of policy, problem and politics streams. The executive order offered a new political venue for decision-making. The unresolved problem of the undocumented immigrant population gained fiscal urgency during the crisis and met with a policy that had been debated for some time already. Some actors claimed their lobbying efforts of the Obama administration for this executive order (Change to Win, NCLR 2012). The unions, civil rights groups and organisations that represent Latino interests welcomed the president's initiative as a first step for large scale legalisation (ACLU, AFL-CIO, Change to Win, NCLR 2012). Others criticised that the executive order bypassed Congress in order to win the vote of the Latino community in the election year (Republican Senator, FAIR 2012). And restrictively-minded groups feared that deferred action allowing for the DREAM Act to be executed would be the wedge for CIR (FAIR 2012).

State legislation on immigration, as well as executive orders, indicate a shift in venues for immigration policy-making. Enforcement is decided on the state level and legalisation of the undocumented is executed by bypassing a Congressional majority. Among the suggested policies that are part of a CIR, unions and employers would only agree on legalisation. Enforcement was not on their agenda and the temporary immigration of workers was heavily contested. Accordingly, the president maintained the status quo and opted for a piecemeal approach on legalisation. Observers from the left deemed this approach as the only way forward in a deadlocked Congress (Interview Change to Win, AFL-CIO, AILA, ACLU 2012).

\footnotetext{
${ }^{13}$ See the agenda of the White House for the Hispanic community from 2012: http://www.whitehouse.gov/sites/default/files/rss_viewer/hispanic_agenda_final.pdf, accessed 8 July 2015.

${ }^{14}$ For the details of the programme, see the website of the Department of Homeland Security:

http://www.dhs.gov/deferred-action-childhood-arrivals, accessed 8 July 2015.
} 
In sum, the absence of policy change on the federal level intensified the problem stream, especially in times of economic crisis. Pressures for change therefore made their way to other venues. Republicans were able to enforce restrictive measures on border protection via the state and local levels, whereas Democrats could implement legalisation schemes through presidential decrees.

\section{Conclusion}

This paper set out to answer the question of what the impact of the economic and financial crisis is on immigration policies in the United States, a country that has been hit hard by this crisis. We find that the crisis has highlighted policy problems that have been present before and has aggravated these problems. US immigration policies have been described as 'bad for migrants, employers and the national interest' (Martin 2011a, 24). Yet, a CIR is stuck in Congress given the absence of strong majorities and the divergent preferences between, but also among, Republicans and Democrats. Policy ideas for liberal and restrictive change have been present for a long time. Moreover, the problem stream is aggravating. In addition the increasing problems of unauthorised border crossings in combination with the hardship of people who have no access to any rights at all based on their undocumented status, motivate both policy proponents of liberalisation and restriction to look for alternative venues to pursue their policy aims. Republicans, who hold the majorities in most state legislatures, pass restrictive policies on the state level where they do not encounter liberal veto players. As far as the Democrats are concerned, the presidential decrees, e.g. the deferred action on childhood arrivals from 2012 and others passed by President Barack Obama in 2014, can equally be considered as an attempt to shop for policy venues where no restrictive veto players can be found (Migration Policy Institute 2014).

The contribution of this article is twofold. On the one hand, we have theorised the current situations of deadlock on the CIR and policy change on the state levels, which have been widely discussed but so far not comprehensively explained. We demonstrate that combining the theoretical approaches of venue-shopping and multiple streams is particularly helpful to understand policy-making under deadlock, as the problem and policy streams would call for change but the politics stream impedes it and so actors search for other venues to pursue their policy aims. This also applies to other policy areas on which the US Congress is currently faced with deadlock. In the case of the EU others have argued that restrictivelyminded ministers of the interior have engaged in 'bottom-up' venue-shopping, i.e. they have 
changed from the national to the EU level to pursue their policy aims (Guiraudon 2000; Maurer and Parkes 2007). Our study adds to this that venue-shopping is not a one-way process, but can also imply 'top-down' venue-shopping and a search for adequate venues on a lower, i.e. subnational level. This seems to be part of a larger phenomenon. Examples for a trend towards devolution of immigration control and enforcement to subnational venues can be found in other federal political systems. More competences for local and regional entities are also claimed in Canada, Spain, the UK, and other countries (Thränhardt 2013). In which way the economic crisis intensified claims for devolution in other cases has yet to be researched.

On the other hand, we show that the crisis has rather aggravated or highlighted problems that have been present for a long time. Thus, the crisis cannot be considered to be the root of current policy change, but rather a moderating variable amplifying the problem pressure that entailed change. This leads us to conclude that external shocks like the global economic crisis never have an immediate impact and are never critical junctures per se but that these rather need to be translated into policy change by political actors. 
Appendix 1

[Table 1 about here] 
Appendix 2: Institutional affiliation of interviewees

[Table 2 about here] 


\section{References:}

Baker, B., and N. Rytina. 2013. Estimates of the Unauthorized Immigrant Population Residing in the United States: January 2012. Population Estimates. Washington D.C.: Department of Homeland Security, Office of Immigration Statistics. http://www.dhs.gov/sites/default/files/publications/ois_ill_pe_2012_2.pdf.

Baumgartner, F. R., and B. D. Jones. 1993. Agendas and instability in American politics. Chicago: Chicago University Press.

Beets, G., and F. Willekens. 2009. The Global Economic Crisis and International Migration: An Uncertain Outlook. The Hague: Netherlands Interdisciplinary Demographic Institute.

Beirich, H. 2009. The Nativist Lobby. Three Faces of Intolerance. A Report from the Southern Poverty Law Centre. Montgomery: Southern Poverty Law Center. http://www.splcenter.org/sites/default/files/downloads/splc_nativistlobby.pdf.

Borjas, G. 2005. "The Economic Benefits from Immigration." Journal of Economic Perspectives 9 (2): 3-22.

Boyer, S. B. 2012. Immigration and Integration in the 2012 U.S. Presidential Race, Perspective. Washington, D.C.: Friedrich Ebert Stiftung. http://library.fes.de/pdffiles/id/09415.pdf.

Coleman, M. 2012. "The "Local" Migration State: The Site-Specific Devolution of Immigration Enforcement in the U.S. South.” Law \& Policy 34 (2): 159-190.

Cornelius, W. A. 2010. "Preface." In Taking Local Control. Immigration Policy Activism in U.S. Cities and States, edited by M. W. Varsanyi, vii-viii. Stanford: Stanford University Press.

Czaika, M., and H. De Haas. 2013. "The Effectiveness of Immigration Policies.” Population and Development Review 39 (3): 487-508. 
Facchini, G., and M. F. Steinhardt. 2011. "What drives U.S. immigration policy? Evidence from congressional roll call votes.” Journal of Public Economics 95 (7): 734-743.

Fennelly, K., K. Pearson, and S. Hackett. 2015. "The US Congressional Immigration Agenda: Partisan Politics, Policy Stalemate and Political Posturing." Journal of Ethnic and Migration Studies: 41 (9): 1412-1432. doi: 10.1080/1369183X.2015.1021586.

Fetzer, J. S. 2006. “Why Did House Members Vote for H.R. 4437?” International Migration Review 40 (4): 698-706.

Freeman, G. P. 2009. "From disordered expansion to disordered stalemate: immigration politics in the United States." In Nations of Immigrants. Australia and the US compared, edited by J. Higley, and J. Nieuwenhuysen, 6-69. Cheltenham: Edward Elgar.

Gilbert, L. 2009. "Immigration as Local Politics: Re-Bordering Immigration and Multiculturalism through Deterrence and Incapacitation." International Journal of Urban and Regional Research 33 (1): 26-42.

Green, T., and A. L. Winters. 2010. "Economic Crises and Migration: Learning from the Past and the Present." The World Economy 33 (9): 1053-1072.

Grusky, D. B., B. Western, and C. Wimer. 2011. "The Consequences of the Great Recession”, In The Great Recession, edited by D. B. Grusk, B. Western, and C. Wimer, 3-20. New York: Russell Sage Foundation.

Guiraudon, V. 2000. "European Integration and Migration Policy: Vertical Policy-Making as Venue Shopping." Journal of Common Market Studies 38(2): 251-271.

Hansen, R. 2009. “Immigration \& Immigration Reform in the United States: An Outsider's View." The Forum 7 (3): 1-13.

Hanson, G. H. 2009. The Economics and Policy of Illegal Immigration in the United States. Washington, D.C.: Migration Policy Institute. 
Hatton, T. J., and J. G. Williamson. 2009. Global economic slumps and migration, VOX CEPR's Policy Portal. http://www.voxeu.org/article/global-economic-slumps-and-migration.

Hoefer, M., B. Baker, and N. Rytina. 2012. Estimates of the Unauthorized Immigrant Population Residing in the United States: January 2011. Population Estimates. Washington, D.C.: Department of Homeland Security, Office of Immigration Statistics. http://www.dhs.gov/xlibrary/assets/statistics/publications/ois_ill_pe_2011.pdf.

U.S. Immigration and Customs Enforcement agencies (ICE). 2014. Delegation of Immigration Authority Section 287(g) Immigration and Nationality Act. http://www.ice.gov/factsheets/287g.

Ilias, S., K. Fennelly, and C. M. Federico. 2008. “American Attitudes towards Guest Worker Policies." International Migration Review 42 (4): 741-766.

Jones, M. P., and B. Chou. 2014. "Immigration Policy and Partisan Politics in the State Legislatures: 2010-2012." In Undecided Nation. Political Gridlock and the Immigration Crisis, edited by T. Payan, and E. de la Garza, 99-119. Cham: Springer.

Jones-Correa, M. 2012. Contested Ground: Immigration in the United States, Washington, D.C.: Migration Policy Institute. http://www.migrationpolicy.org/sites/default/files/publications/TCM-UScasestudy.pdf.

Kingdon, J. W. 1995. Agendas, Alternatives, and Public Policies. 2nd ed. New York: Longman.

Lopez, M. H., and S. Minushkin. 2008. 2008 National Survey of Latinos: Hispanic Voter Attitudes. Washington, D.C.: Pew Research http://www.pewhispanic.org/files/reports/90.pdf.

Mansbridge, J. and, C. J. Martin eds. 2013. Negotiating Agreements in Politics. Report of the Task Force on Negotiating Agreement in Politics. Washington, D.C.: American Political Science Association. 
Marquez, B., and J. F.Witte. 2009. Immigration Reform: Strategies for Legislative Action. The Forum 7 (3): 1-28.

Martin, C. J. 2013. "Negotiating Political Agreements." In Negotiating Agreements in Politics. Report of the Task Force on Negotiating Agreement in Politics, edited by J. Mansbridge, and C. J. Martin, 1-18. Washington, D.C.: American Political Science Association.

Martin, P. 2011a. "Immigration, labour markets and immigration reform in the United States." In Immigration and the Financial Crisis. The United States and Australia Compared, edited by J. Higley, J. Nieuwenhuysen,, and S. Neerup, 16-34. Cheltenham: Edward Elgar.

Martin, P. 2011b. "Mexico-US Migration, NAFTA and CAFTA, and US Immigration Policy.” In Migration, Nation States, and International Cooperation, edited by R. Hansen, J. Koehler, and J. Money, 75-86. New York: Routledge.

Massey, D., and F. Riosmena. 2010. "Undocumented Migration from Latin America in an Era of Rising U.S. Enforcement." The Annals of the American Academy of Political and Social Science 630 (1): 294-321.

Maurer, A. and R. Parkes. 2007. "The Prospects for Policy Change in EU Asylum Policy: Venue and Image at the European Level.” European Journal of Migration and Law 9 (2): 173-205.

McCarthy, N. 2007. "The Policy Effects of Political Polarization.” In The Transformation of American Politics. Activist Government and the Rise of Conservatism, edited by P. Pierson, and T. Skocpol, 223-255. Princeton: Princeton University Press.

Migration Policy Institute. 2014. MPI: As Many as 3.7 Million Unauthorized Immigrants Could Get Relief from Deportation under Anticipated New Deferred Action Program. Washington D.C.: MPI Press Release. http://www.migrationpolicy.org./. 
Migration Policy Institute. 2013. Key Immigration Laws and Policy Developments since 1996, $\begin{array}{llll}\text { Washington } & \text { D.C.: } & \text { PPI } & \text { Press }\end{array}$ http://www.migrationpolicy.org/sites/default/files/publications/CIR-1986Timeline.pdf.

Milner, H. V., and D. Tingley. 2008. The Economic and Political Influences on Different Dimensions of United States Immigration Policy, Working Paper prepared for the Midwest $\begin{array}{llll}\text { Political Science Mssociation } & \text { Meeting. }\end{array}$ http://www.princeton.edu/ hmilner/working\%20papers/The\%20Economic\%20and\%20Politic al\%20Influences\%20on\%20Different\%20Dimensions\%20of\%20United\%20States\%20Immig ration\%20Policy.pdf.

Newton, L. 2008. Illegal, Alien, or Immigrant. The Politics of Immigration Reform. New York: New York University Press.

Papademetriou, D. G., and A. Terrazas. 2010. "Immigrants and the US Economic Crisis: From Recession to Recovers." In Migration and Immigrants Two Years after the Financial Collapse: Where Do We Stand?, edited by D. G. Papademetriou, M. Sumption, A. Terrazas, C. Burkert, S. Loyal, and R. Ferrero-Turrión, 22-46. Washington, DC: Migration Policy Institute.

Pew Research Center. 2013. Most Say Immigration Policy Needs Big Changes. But Little Agreement on Specific Approaches. Washington, D.C.: Pew Research Center. http://www.people-press.org/files/legacy-pdf/5-9-13\%20Immigration\%20Release.pdf.

Pew Research Center. 2006. Modes of Entry for the Undocumented Migrant Population. Washington, D.C.: Pew Research Center. http://pewhispanic.org/files/factsheets/19.pdf.

Rosenblum, M. R. 2011. US Immigration Policy Since 9/11: Understanding the Stalemate over Comprehensive Immigration Reform. Washington, D.C.: Migration Policy Institute. http://www.migrationpolicy.org/sites/default/files/publications/RMSG-post-9-11policy.pdf.

Schain, M. A. 2012. The Politics of Immigration in France, Britain, and the United States. A Comparative Study. 2nd ed. New York: Palgrave Macmillan. 
Schain, M. A. 2006. "The politics of immigration in France, Britain and the United States. A transatlantic comparison." In Immigration and the Transformation of Europe, edited by C. A. Parsons, and T. M. Smeeding, 362-392. Cambridge: Cambridge University Press.

Steil, J. P., and I. B. Vasi. 2014. "The New Immigration Contestation: Social Movements and Local Immigration Policy Making in the United States, 2000-2011.” American Journal of Sociology 119 (4): 1104-1155.

Suro, R. 2005. Attitudes toward Immigrants and Immigration Policy: Surveys among US Latinos and in Mexico. Washington, D.C.: Pew Hispanic Center. http://www.pewhispanic.org/files/reports/52.pdf.

Thränhardt, D. 2013. "Immigration and Integration in European Federal Countries: A Comparative Evaluation." In Immigration and Federalism in Europe. Federal, Stat and Local Regulatory Competencies in Austria, Belgium, Germany, Italy, Russia, Spain and Switzerland, edited by D. Thränhardt, 7-20, Osnabrück: IMIS.

Tichenor, D. J. 2014. “The Congressional Dynamics of Immigration Reform.” In Undecided Nation. Political Gridlock and the Immigration Crisis, edited by T. Payan, and E. de la Garza. 23-48. Cham: Springer.

Tilly, C. 2011. "The impact of the economic crisis on international migration: a review." Work, employment and society 25 (4): 675-692.

Varsanyi, M. W. 2010. "Immigration Policy Activism in U.S. Cities and States: Interdisciplinary Perspectives." In Taking Local Control. Immigration Policy Activism in U.S. Cities and States, edited by M. W. Varsanyi, 1-27. Stanford: Stanford University Press.

Varsanyi, M. W. 2008. "Immigration Policing Through the Backdoor: City Ordinances, the "right to the City," and the Exclusion of Undocumented Day Laborers." Urban Geography 29 (1): 29-52.

Wishnie, M. J. 2002. "Introduction: Immigration and Federalism." Annual Survey of American Law 58 (3), 283-293. 
Zolberg, A. R. 2008. A Nation by Design. Immigration Policy in the Fashioning of America. Cambridge, MA: Harvard University Press. 
Tables and Figures

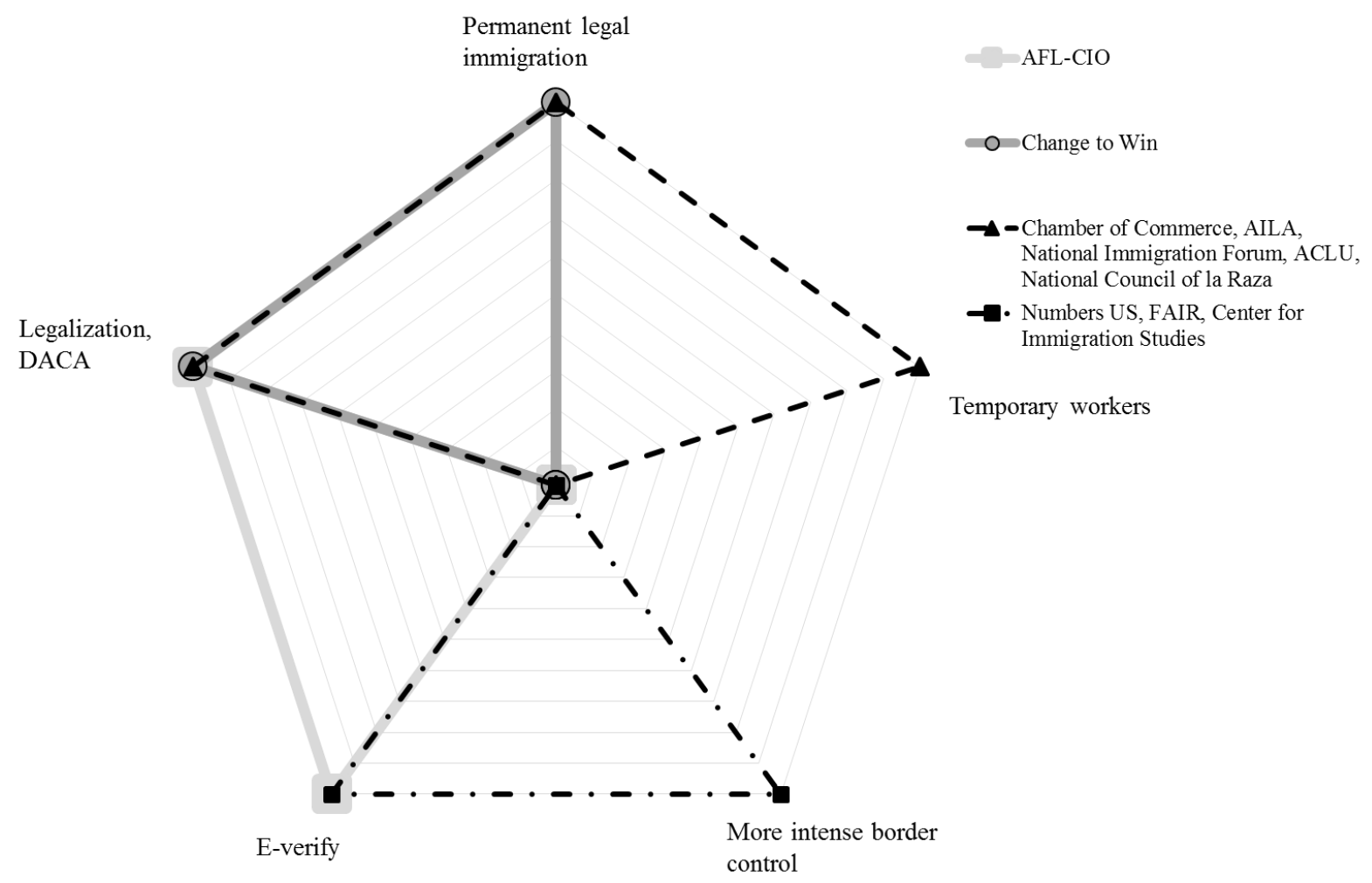

Figure 1. Interest group positions on immigration reform 


\begin{tabular}{|c|c|c|c|c|c|c|}
\hline \multirow[t]{2}{*}{ Interest group } & \multicolumn{3}{|c|}{ Admission } & \multicolumn{2}{|c|}{ Enforcement } & \multirow{2}{*}{$\begin{array}{l}\quad \text { Amnesty } \\
\text { Legalisation, } \\
\text { DREAM Act } \\
\text { (DACA, deferred } \\
\text { action for childhood } \\
\text { arrivals) }\end{array}$} \\
\hline & $\begin{array}{l}\text { Permanent legal im } \\
=\text { Family } \\
\text { Economic migration }\end{array}$ & gration & Temporary workers & $\begin{array}{l}\text { More intense } \\
\text { border control, } \\
\text { apprehension and } \\
\text { deportation, local } \\
\text { enforcement by } \\
\text { states }\end{array}$ & $\begin{array}{l}\text { E-verify } \\
\text { "employer } \\
\text { verification"1 }\end{array}$ & \\
\hline Change to Win & $\begin{array}{l}\text { Yes } \\
=\text { permanent legal ir }\end{array}$ & nigration & No & No & No & Yes \\
\hline
\end{tabular}




\begin{tabular}{|c|c|c|c|c|c|c|}
\hline Interest group & \multicolumn{3}{|c|}{ Admission } & \multicolumn{2}{|c|}{ Enforcement } & \multirow{2}{*}{ Amnesty } \\
\hline Numbers US & $\begin{array}{l}\text { Yes, for spouses and minor } \\
\text { children, no chain migration }\end{array}$ & \multicolumn{2}{|c|}{$\begin{array}{l}\text { Lower ceilings, open to skilled, } \\
\text { cut the diversity and green card } \\
\text { lottery }\end{array}$} & Yes & Yes & \\
\hline FAIR & \multicolumn{3}{|c|}{ Lower ceilings overall, focus on skills } & Yes & Yes & No \\
\hline AILA & $\begin{array}{l}\text { Yes } \\
\text { Family migration as well as } \\
\text { economic migration is } \\
\text { supported }\end{array}$ & \multicolumn{2}{|c|}{$\begin{array}{l}\text { Yes } \\
\text { Facilitations for temporary } \\
\text { worker programmes are } \\
\text { demanded }\end{array}$} & $\begin{array}{l}\text { No increase in } \\
\text { control }\end{array}$ & $\begin{array}{l}\text { No } \\
\text { E-verify is flawed } \\
\text { and puts a burden } \\
\text { on businesses }\end{array}$ & Yes \\
\hline $\begin{array}{l}\text { National } \\
\text { Immigration Forum }\end{array}$ & \multicolumn{3}{|l|}{ Yes on all issues } & $\begin{array}{l}\text { No } \\
\text { Further } \\
\text { enforcement, } \\
\text { control intensity } \\
\text { and costs are too } \\
\text { high already }\end{array}$ & $\begin{array}{l}\text { No } \\
\text { Do not punish } \\
\text { workers for an } \\
\text { immigration system } \\
\text { that does not work }\end{array}$ & Yes \\
\hline $\begin{array}{l}\text { Center for } \\
\text { Immigration Studies }\end{array}$ & \multicolumn{2}{|c|}{$\begin{array}{l}\text { Lower ceilings } \\
\text { Saturation point reached with immigration } \\
\text { Get rid of family unity }\end{array}$} & $\begin{array}{l}\text { Focus on people } \\
\text { who can help the } \\
\text { economy get going } \\
\text { again }\end{array}$ & Yes & $\begin{array}{l}\text { Yes } \\
\text { Keep undocumented } \\
\text { immigrants from } \\
\text { being hired }\end{array}$ & No \\
\hline
\end{tabular}




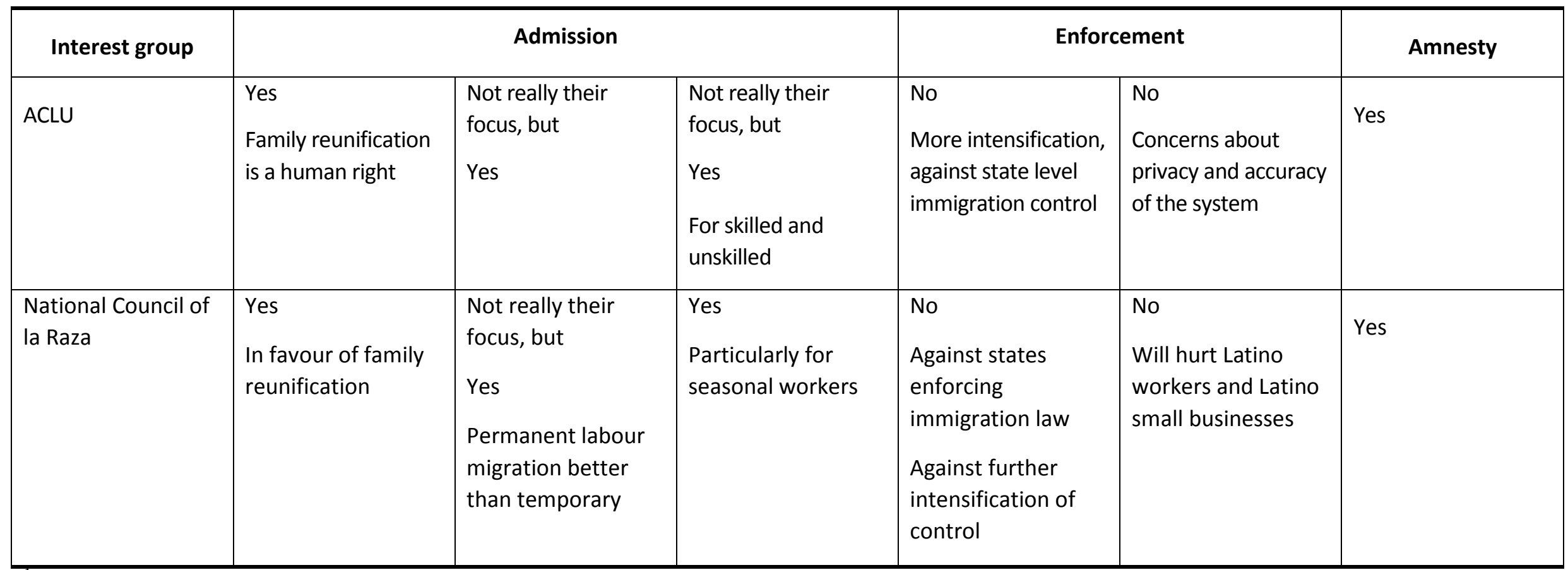

${ }^{1}$ Employer verification systems are used to check workers' employment eligibility (now referred to as E-Verify) (see Rosenblum 2011: 6).

Table 1. Detailed interest group positions on immigration reform 
Table 2. Institutional affiliation of interviewees

\begin{tabular}{ll}
\hline Institutional affiliations of US interviewees & $\begin{array}{l}\text { Date of Interview } \\
\text { Washington D.C. }\end{array}$ \\
\hline American Immigration Lawyers Association (AILA) & 11 September 2012 \\
Immigration Policy Center & 1 September 2012 \\
American Federation of Labor and Congress of Industrial Organizations (AFL-CIO) & 11 September 2012 \\
& 15 October 2012 \\
Federation for American Immigration Reform (FAIR) & 12 September 2012 \\
US Chamber of Commerce & 13 September 2012 \\
Numbers USA & 13 September 2012 \\
Change to Win & 14 September 2012 \\
Republican Senator & 17 September 2012 \\
National Immigration Forum & 17 September 2012 \\
Center for Immigration Studies & 18 September 2012 \\
American Civil Liberties Union (ACLU) & 18 September 2012 \\
National Council of La Raza (NCLR) & 19 September 2012 \\
\hline
\end{tabular}

